\title{
A monitoring strategy in view of Water Framework Directive requirements with focus on anthropogenic micropollutants
}

\author{
A. Brunsch \\ Erftverband, Germany
}

\begin{abstract}
The Water Framework Directive of the European Commission sets down regulatory requirements regarding harmful chemical substances in surface waters and measures to reduce such presence. Member states are responsible for implementation. In Germany the surface water ordinance (Oberflächengewässerverordnung) was adopted for this purpose in 2011. Currently the matter of whether to extend the list of substances to be reduced or eliminated in surface waters is being reconsidered. Among the types of substances under discussion are pharmaceuticals. To fulfil the requirements of the Water Framework Directive, it is essential that sophisticated local monitoring programs be conducted to obtain a useful knowledge base regarding the water quality situation of surface waters. Such a program is applied to the Swist watercourse, a tributary of the Rhine river. One component is establishment of a balancing of emissions for the purpose of identifying relevant sources, pathways and inputs of pollutants. Monitoring data is thus obtained from various source areas such as wastewater treatment plants, sewerage system outlets and runoff from landscape. To understand cause-effect relationships and to validate emission data, an immission monitoring strategy has also been established for the Swist. Furthermore, a scenario based measuring initiative with focus on anthropogenic micropollutants has been recently introduced into the existing monitoring program. This initiative is being conducted to expand knowledge of both the fate and behaviour of anthropogenic micropollutants in the Swist watercourse. First results show the appearance of a range of micropollutants, with highest concentrations of Diclofenac, Carbamazepin and Diatrizoat.
\end{abstract}

Keywords: monitoring, emission sources, anthropogenic micropollutants, priority substances, water management. 


\section{Introduction}

To meet the objectives of the Water Framework Directive (WFD) regarding chemical substances, those responsible for water management depend upon the availability of significant water quality data. Besides metals, industrial chemicals and pesticides, a focus is nowadays also on residues of pharmaceuticals and personal care products in the aquatic environment. Through improved analytical techniques, it has become easier to identify micropollutants in even very small quantities. Monitoring studies have shown that pharmaceutical residues are extensively found in the environment. Moreover, there is a need to reduce the impact of pharmaceuticals on the environment, for precautionary reasons alone (Rönnefahrt et al. [1]). However, pollutants in the aquatic environment may depend on the geographical situation as well as anthropogenic influences. A suitably designed monitoring program featuring a balancing of pollution source areas is thus a precondition for success in achieving good ecological and chemical status as defined by the WFD.

\section{Study area}

One such monitoring strategy is utilised for the Swist, a lowland stream which is part of the Rhine river catchment in North Rhine Westphalia, Germany. The catchment of the Swist is almost $300 \mathrm{~km}^{2}$ in area. The average discharge measured from 1972 to 2001 near the mouth was $1.01 \mathrm{~m}^{3} / \mathrm{s}$; the average low water discharge was $0.129 \mathrm{~m}^{3} / \mathrm{s}$ (Ministerium für Umwelt und Naturschutz, Landwirtschaft und Verbraucherschutz NRW [2]).

Specific to the Swist catchment is high population density coexists with high agricultural activity. The discharge of the Swist is greatly affected by outlets of wastewater treatment plants, separate sewer outlets and combined sewer overflows. Per year, a total of $6,900,000 \mathrm{~m}^{3}$ of treated wastewater from four plants is pumped into the Swist (Christoffels [3]). This is equivalent to a daily average $(\mathrm{Q} / 14 \mathrm{~h})$ of $0.38 \mathrm{~m}^{3} / \mathrm{s}$ (factor $\mathrm{x}_{\text {daily average }}=1 / 14$ according to Imhoff and Imhoff [4]).

\section{Relevant European and German Directives to reduce chemical pollution in surface waters}

With the establishment of Directive 2000/60/EC (Water Framework Directive) by the European Union [5], water protection and management of river basins made a significant progress. With its aim of achieving good ecological status or good ecological potential and good chemical status by the end of 2015, the Directive formulates an approach which meets the needs of sustainable development. This includes improving aquatic ecosystems and reducing pollution.

Annex IX of Directive 2000/60/EC covers emission limit values and environmental quality standards (EQS) necessary to reach good chemical status of surface waters. The pollutants named in Annex IX are referred to in Directive 
76/464/EEC on pollution caused by certain dangerous substances discharged into the aquatic environment of the Community and in additional Directives which cover a number of substances comprehensively (The Mercury Discharge Directive; The Cadmium Discharge Directive; The Mercury Directive; The Hexachlorocyclohexane Discharge Directive and The Dangerous Substance Discharge Directive).

Decision 2455/2001/EC of November 2001 defines 33 priority substances or groups of substances for action at Community level. This Decision requires continuous reduction in their concentrations. The 33 priority substances include metals, metal compounds, pesticides, biocides and industrial chemicals. Some of them have also been identified as priority hazardous substances for which necessary measures requiring the ceasing or phasing out of emissions, discharges and losses are to be implemented within 20 years.

Directive 2008/105/EC [6] adopts corresponding environmental quality standards for these 33 priority substances, indicated as annual average and maximum allowable concentration. The European Commission calls for a review and update of the list of prioritised substances every four years.

The clear objective in defining concentration limits for prioritised substances is to ensure good chemical status of surface waters. However, the Water Framework Directive regulates not only chemical status but also ecological status, which provides a measure of a healthy ecosystem. In order to meet this requirement, every Member State needs to control additional pollutants of national relevance.

In Germany a federal surface water ordinance (Oberflächengewässerverordnung) [7] was adopted in 2009. For classification of chemical status, the surface water ordinance adopts the list of priority substances including environmental quality standards set down in Directive 2008/105/EC. For classification of ecological status, the surface water ordinance provides a list of 162 river basin specific substances which must be observed and controlled if there is significant pollution through discharge in the watercourse. Unlike priority substances for which the EQS must be determined by annual average and maximum allowable concentration, the EQS of the river basin specific substances need only be determined by annual average.

Up to now, pharmaceuticals have not been comprised in the Directive 2008/105/EC [6]. The same applies for the 162 river basin specific substances listed in the surface water ordinance. Although some pharmaceuticals (Carbamazepin and Sulfamethoxazol) were originally proposed for inclusion, they were withdrawn on the basis of a Federal Council Decision Drucksache 153/11 [8]. However, the Water Framework Directive calls for provision of a new list of priority substances every four years. In this context, on 31 January 2012 the European Commission brought out a proposal for a Directive amending priority substances in Directive 2000/60/EC and Directive 2008/105/EC [9]. In developing the revised list of prioritised substances, 15 additional substances have been proposed. Besides pesticides, biocides and industrial chemicals, three active pharmaceutical ingredients are also included: $17 \alpha$-Ethinylestradiol, $17 \beta$ Estradiol and Diclofenac. 
Table 1: Overview of Environmental Quality Standards relevant to German surface waters.

\begin{tabular}{|c|c|c|c|c|c|}
\hline \multicolumn{4}{|c|}{ Classification of chemical status } & \multicolumn{2}{|c|}{$\begin{array}{l}\text { Classification of ecological } \\
\text { status (specific synthetic } \\
\text { and non-synthetic } \\
\text { pollutants) }\end{array}$} \\
\hline \multicolumn{4}{|c|}{ Regulated on European basis } & \multicolumn{2}{|c|}{$\begin{array}{l}\text { Regulated on National } \\
\text { basis }\end{array}$} \\
\hline \multicolumn{4}{|c|}{ Priority substances } & \multicolumn{2}{|c|}{$\begin{array}{l}\text { River basin specific } \\
\text { substances }\end{array}$} \\
\hline $\begin{array}{c}\text { Priority } \\
\text { hazardous } \\
\text { substance }\end{array}$ & $\begin{array}{c}\text { AA EQS } \\
{[\mu \mathrm{g} / 1]}\end{array}$ & $\begin{array}{c}\text { MAC EQS } \\
{[\mu \mathrm{g} / 1]}\end{array}$ & $\begin{array}{c}\text { EQS biota } \\
{[\mu \mathrm{g} / \mathrm{kg}]}\end{array}$ & $\begin{array}{c}\text { AA EQS } \\
{[\mu \mathrm{g} / 1]}\end{array}$ & $\begin{array}{c}\text { EQS } \\
\text { suspended } \\
\text { load / } \\
\text { sediment } \\
{[\mathrm{mg} / \mathrm{kg}]}\end{array}$ \\
\hline \multicolumn{6}{|c|}{ EQS = Environmental Quality Standard; AA = Annual Average } \\
\hline
\end{tabular}

\section{Monitoring program as applied to the Swist watercourse}

A useful knowledge base regarding the water quality situation is required in order to achieve the objectives as presented in part 3. To enable precise characterisation of the immission situation for watercourses it is first necessary to characterise the emissions in the catchment area. Consequently, relevant sources, pathways and inputs of pollutants must be identified. Monitoring is hence performed using diverse techniques. It may be continuous, episodic or event-specific depending on the measurement objective, method and prevailing amount of precipitation in the catchment area.

\subsection{Methods of emission monitoring}

Relevant emissions in the Swist catchment include surface runoff, subsurface flow, natural groundwater flow and urban effluents. The latter mainly flow from wastewater treatment plants (WWTPs) and sewerage system outlets. The following discussion will cover measures for monitoring urban effluents and landscape runoff.

\subsubsection{Point sources}

Precipitation-induced emissions in urban areas are in the first instance reflected by combined sewer overflows (CSO) and by outflows from separate sewerage outlets (SSO). The emission inventory for combined sewer overflows is based upon reliable data for volume and substance concentration of discharge. A number of the storm water retention tanks deployed in the combined sewerage systems in the Swist basin have been equipped with flow gauges. Thus, it has been possible to obtain long term, reliable discharge volume data at these locations. It follows that substance monitoring could also be successfully 
undertaken here. The goal is to determine approximate concentration ranges for a wide variety of substances stemming from CSOs.

In one of the combined sewerage systems, a soil filter retention site has been established. It has been set up to reduce heavy pollution from peak discharge values of excess wastewater flowing out of storm water retention tanks by performing advanced purification. Before discharge into watercourses, the water is held in the retention basin, which is planted with reeds. Here the water slowly diffuses through a soil filter. Undesirable water components are adsorbed and biologically degraded.

Hardly any monitoring data is available describing the quality of discharges from SSOs, which drain and collect water from rainfall in urban areas. For this reason a monitoring system has been established at the Meckenheim stormwater retention tank in the Swist river catchment.

The ability to sample blast events at any time has been assured by installing automatic sampling systems with programmable logic controllers. Those have been set up on certain sampling points on one SSO, CSO and the soil retention site. Water samples are taken by an immersion pump. The programmable logic controller also sends a message to staff once the sampling device is activated. In this way samples can be analysed in a timely manner.

Besides determining pollution from CSOs and SSOs, ascertaining load stemming from wastewater treatment plant outflow is essential in order to establish a valid emission inventory in a high-population-density catchment such as that of the Swist river. Effluent load is assessed in terms of discharge volume and substance concentration.

\subsubsection{Non-point sources}

Besides encompassing discharge data from the point sources of WWTPs, SSOs and CSOs, a complete emission inventory accounts for volume and substance concentration of discharges from non-point sources: overland flow and subsurface flow (interflow).

Discharge volumes from these categories of non-point sources can be quantified by basin wide application of a precipitation runoff model (NASIM ${ }^{\odot}$ ). Additionally, a sampling method provides the ability to collect monitoring data on surface and subsurface flow which can be used to determine substance concentrations. Integrated in the monitoring system, this sampling method permits separate capture of runoff from surface waters (overland flow) and runoff from soil moisture (subsurface flow) from land under various utilisations. Four distinct land uses have been considered: forest; pasture; cropland and orchard (Christoffels [10]).

\subsection{Methods of immission monitoring}

With the emission inventory established, immission monitoring strategies are being developed and implemented for the purpose of validating the emission data obtained. For this purpose, both conventional methods and new ones are employed. Under conventional methods, samples of flowing water are collected twice a year at six sampling points for physical, chemical and biological 
examinations at the beginning of the growing season in spring and at the end of the growing season in autumn. Additionally, for continuous recording of contents of surface water, an online monitoring station has been established. With this system data can be collected on the most important water quality parameters. For a number of important parameters, a data collection station has been established with computers connected online to central processing facilities e.g. via the standard telecommunication network. Data is then recorded continuously and transmitted automatically or on demand. At the central facility the measurement data are processed to yield information needed to assess and if necessary to improve water quality (Christoffels [11]).

\subsection{Substances included in the monitoring program}

The broad variety of parameters and substances (listed below) have been selected for testing within the Swist emission and immision monitoring program because together they provide a detailed overview of water quality situations in the river. They are also selected according to the specifications of the Directives for reducing chemical pollution in surface waters (see part 3).

- General parameters (like temperature; oxygen; pH-value; hardness; turbidity; residues; suspended solids and certain cations).

- Organoleptic parameters.

- Oxygen depletion indicators.

- Nitrogen.

- Phosphorous.

- Salt contents.

- Heavy metals and other metals.

- Organic halogens.

- Pathogenic germs.

- Pesticides and biocides.

- Pharmaceuticals and personal care products.

\subsection{Micropollutant monitoring strategy}

To understand the water quality conditions of a river it is also important to know the fate and behaviour of micropollutants in the environment. For this reason as well as to meet the objectives of the WFD (see part 3), micropollutants such as pesticides and pharmaceuticals are receiving increasing attention in water quality management. However, data available from literature about emission and behaviour of micropollutants in river systems is still insufficient. Furthermore, the concentration of pollution which appear in its surface waters are specific to a river basin with its own hydrological and climatological conditions. For this reason a scenario based measuring initiative with focus on anthropogenic micropollutants is being progressively introduced into the existing Swist monitoring program. The applied method as well as first results are presented below. 


\subsubsection{Micropollutant monitoring method}

The following substance groups, which are discharged through point and nonpoint sources, are relevant to the Swist micropollutant monitoring: antibiotics, beta blockers, estrogens, other human and veterinarian pharmaceuticals, musks, $\mathrm{x}$-ray contrast media, pesticides, biocides and plastic additives.

In order to distinguish the sources of the observed substances and to differentiate between non-point and point sources of pollution, samples are taken from diverse measuring points as described in part 4.1 and 4.2. To identify various input sources of emission, measuring points are placed at the outlets of five wastewater treatment plants, one combined sewer overflow and one separate sewerage outlet. Landscape runoff, measured as surface and subsurface runoff by means of sampling devices placed in various land use areas is also taken into account. Additionally, to observe immission loads in the river, multiple sampling on six measuring points along the Swist watercourse is to be performed.

It is expected that pollutant concentration in the watercourse will exhibit some variation. This assumption is based on varying amounts of pollution discharge into the watercourse due to prevailing weather conditions and seasonality. For this reason, monitoring to measure micropollutant load is to be performed under three diverse types of weather conditions: dry weather, steady rain and heavy rain. To get a first overview, samples are collected twice under each type of weather condition, for a total of six sampling batches. In order to cover the variation of loads during one year, seasonality is taken into account within the monitoring program.

\subsubsection{Micropollutants in wastewater and watercourse}

Two sampling batches including analyses of the samples were completed in September and November 2011 under dry weather conditions. The preliminary evaluation of these first two sets of sampling results reveals the presence of substances in treated sewage water as well as in surface waters. The concentration of pesticides in the watercourse was low because in September and November there is relatively little application of pesticides on farmland. Furthermore, the measured values obtained are related to long dry periods in which there was no pollution input through surface runoff and subsurface runoff. For these reasons only the results of loads from pharmaceuticals and personal care products are shown and discussed in the following.

Figure 1 shows the median and the maximum concentration of substances at the outlet of wastewater treatment plants and in the Swist, exceeding the limits of quantification. In the upper reach of the Swist, with no wastewater treatment plants present, no micropollutants were detected. However, in the middle and lower reaches of the Swist, with a higher population density, micropollutants were recorded. Data presented in the figure refer to the measuring points in the middle and lower reaches. 


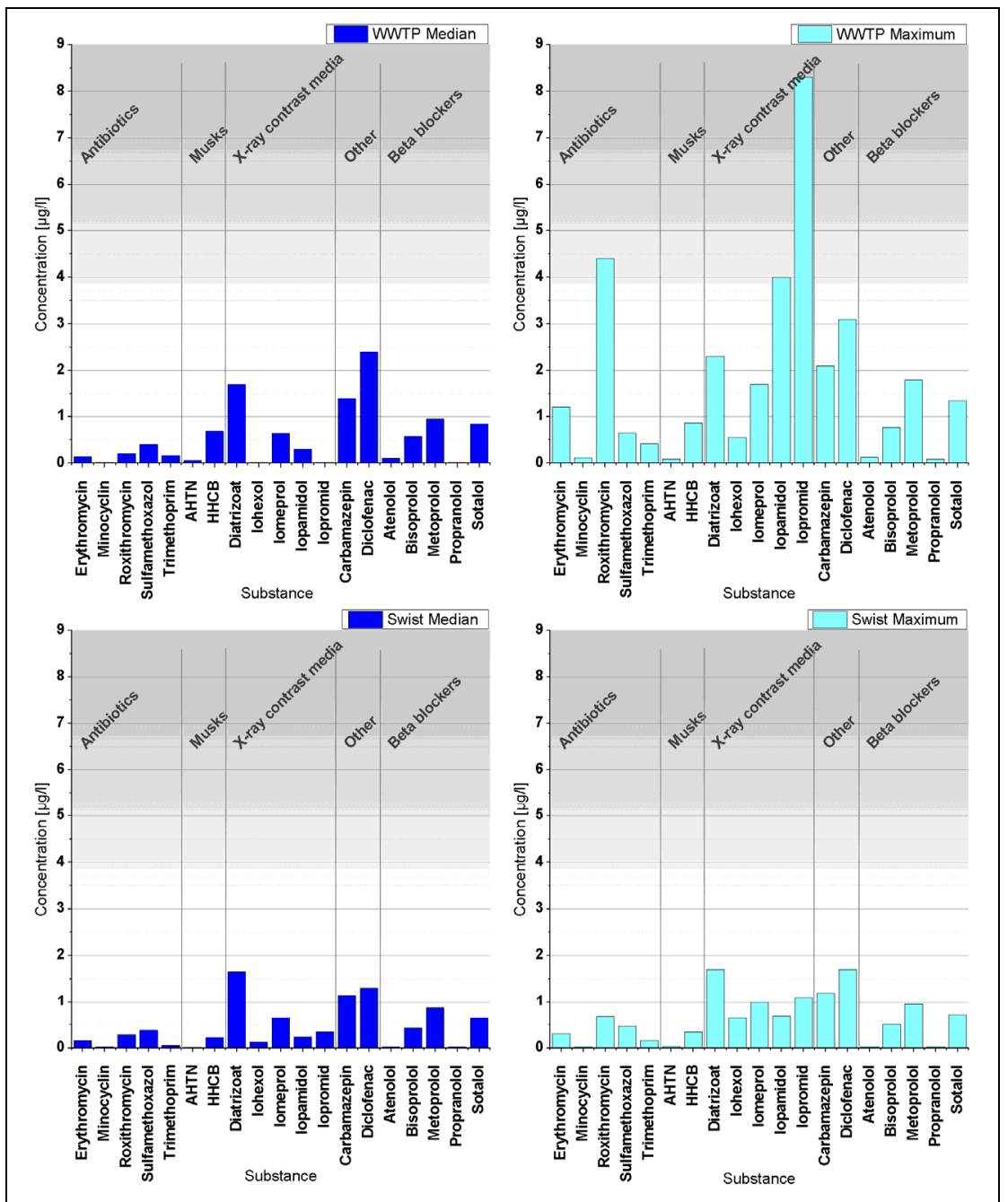

Figure 1: Loads at the outlet of wastewater treatment plants and in the Swist watercourse; dry weather scenario.

Diclofenac, Diatrizoat and Carbamazepin were the substances with highest median concentrations at the outlets of wastewater treatment plants and in the watercourse. Looking at maximal concentrations at both WWTP outlets and in the watercourse, it is noticeable that iodinated X-ray contrast media have a strong presence. The concentration of the antibiotic Roxithromycin, also measured at the outlet of a WWTP, was also conspicuously high at $4.4 \mu \mathrm{g} / \mathrm{l}$. Among the beta blockers, Bisoprolol, Metoprolol and Sotalol were the most frequent. The highest detected value in the Swist of the poorly degradable musk compound HHCB stood at $0.34 \mu \mathrm{g} / \mathrm{l}$. 


\subsubsection{Results for the newly proposed priority substance Diclofenac}

The suggested EQS annual average from the European Commission [9] for Diclofenac has been specified as $0.1 \mu \mathrm{g} / \mathrm{l}$ for inland surface waters. For the Swist watercourse the median concentration was $1.3 \mu \mathrm{g} / \mathrm{l}$. On the one hand, it has to be considered that the samples were taken under prolonged dry weather conditions with no diluting effects from precipitation. On the other hand, there was no untreated wastewater from combined sewer overflows at this stage sampling, which would have carried more substances into the watercourse. Whatever the explanation, the high median concentration measured in this first round of sampling suggests that the annual average of Diclofenac may exceed the EU proposed limit value. Results from monitoring under conditions of steady rain and heavy rain are still awaited.

\section{Conclusion}

The emission balancing as implemented on the Swist watercourse is conducted with monitoring points situated on the most important emission pathways. Immission monitoring will subsequently help determine cause-effect relationship between emissions and water quality. It is thus anticipated that the monitoring program now being put in place will prove its worth by providing a clear view of the water quality situation and sources of pollution in the Swist river catchment.

This existing monitoring program also makes it simple to introduce new monitoring strategies as demonstrated by the example of micropollutant monitoring. This is pertinent in light of the fact that the list of priority substances is subject to revision every four years.

In the water sector measures against harmful substances in surface waters need to be discussed, which is also confirmed by the first results of the micropollutant monitoring program. The knowledge based on the applied monitoring program will facilitate the selection of measures to reduce pollutants according to the provisions of the European Water Framework Directive and the German surface water ordinance. If the emission sources are known, it is possible to place such measures targeted. Measures like the introduction of a 4th sewage treatment step, retention soil filters downstream CSOs and SSOs, extended buffer stripes along the river or built-in filter system on the outlet of drainage pipes are under discussion.

\section{Acknowledgement}

Development and deployment of the monitoring systems presented in this paper has been funded in the framework of the European Union initiative Life+, within which the $\mathrm{M}^{3}$-project "Application of integrated modeling and monitoring approaches for river basin management evaluation" has been established. The European Union is gratefully acknowledged for its support and funding initiatives. 


\section{References}

[1] Rönnefahrt, I., Amato, R., Ebert, I.and Schönfeld, J. Arzneimittel in der Umwelt - Ein Risiko? UMID. Umwelt und Mensch - Informationsdienst 1/2012, ed. BfS, BfR, RKI, UBA: Berlin, pp. 36-43, 2012.

[2] Ministerium für Umwelt und Naturschutz, Landwirtschaft und Verbraucherschutz NRW. Mikrobielle Fließgewässerbelastungen durch abwassertechnische Anlagen und diffuse Einträge, Düsseldorf, 2009.

[3] Christoffels, E. Chemisch-physikalische Stoffeinträge in die Fließgewässer aus den Abflusskomponenten des Landschaftswasserhaushalts. 43. Essener Tagung für Wasser- und Abfallwirtschaft "Perspektiven und Risiken": Aachen, 2010.

[4] Imhoff, K. and Imhoff, K. R. Taschenbuch der Stadtentwässerung, Verlag Oldenbourg: München, 1999.

[5] European Commission. Directive 2000/60/EC of the European Parliament and of the Council of 23 October 2000 Establishing a Framework for Community Action in the Field of Water Policy. Office Journal L 327/1, 2000.

[6] European Commission. Directive 2008/105/EC of the European Parliament and of the Council of 16 December 2008 on environmental quality standards in the field of water policy, amending and subsequently repealing Council Directive 82/176/EEC, 83/513/EEC, 84/156/EEC, 84/491/EEC, 86/280/EEC and amending Directive 2000/60/EC of the European Parliament and of the Council. Office Journal L 348/84, 2008.

[7] OGewV. Oberflächengewässerverordnung vom 20. Juli 2011 (BGBl. I S. 1429), 2011.

[8] Bundesrat. Drucksache 153/11 (Beschluss). Beschluss des Bundesrates. Verordnung zum Schutz der Oberflächengewässer (Oberflächengewässerverordnung - OgewV), 2011.

[9] European Commission. Proposal for a Directive of the European Parliament and of the Council amending Directives 2000/60/EC and 2008/105/EC as regards priority substances in the field of water policy. COM (2011) 876 final 2011/0429 (COD), 2012.

[10] Christoffels, E. Chemisch-physikalische Stoffeinträge in die Fließgewässer aus den Abflusskomponenten des Landschaftswasserhaushalts Teil 2: Technik, Ergebnisse und Plausibilitätsuntersuchungen. Korrespondenz Wasserwirtschaft, 10 (4), pp. 548-552, 2011.

[11] Christoffels, E. Monitoring und Modellanwendung - Entwicklung eines Immissionsinventars am Beispiel der Erft, ed. Erftverband: Bergheim, 2008. 